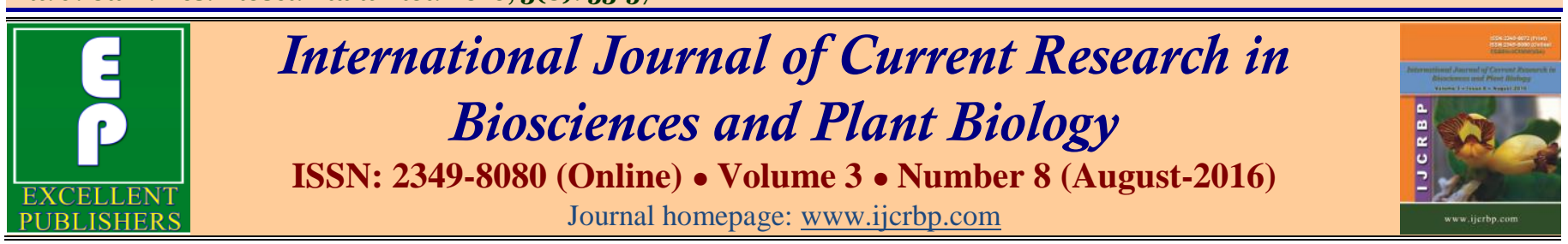

\title{
The Phytochemical Constituents of Vossia cuspidata and Synedrella nodiflora
}

\author{
Ejoba Raphael ${ }^{*}$, Sanni Momoh', Dansofojo Kayode², Ayeni Gideon' ${ }^{1}$ and \\ Emmanuel T. Friday ${ }^{1}$ \\ ${ }^{1}$ Department of Biochemistry, Kogi State University, Anyigba, Nigeria \\ 2Department of Medicinal Biochemistry, Cross River State University of Science and Technology, Okuku-Ogala, \\ Cross River, Nigeria \\ *Corresponding author.
}

\begin{tabular}{|c|c|}
\hline Abstract & Article Info \\
\hline \multirow{3}{*}{$\begin{array}{l}\text { An investigation into the bioactive compounds in Synedrella nodiflora (leaf) and Vossia } \\
\text { cuspidata (stem) was carried out. Soxhlet extraction, aqueous extraction and wet } \\
\text { extraction methods were carried out using chloroform and water as the solvents. The } \\
\text { extract obtained for Vossia cuspidata stems was } 14.0 \%, 12.6 \% \text { and } 7.85 \% \text { while that of } \\
\text { Synedrella nodiflora leaves were } 11.85 \%, 9.05 \% \text { and } 5.30 \% \text { respectively. } \\
\text { Phytochemical analysis of Vossia cuspidata stem showed the presence of carbohydrates, } \\
\text { glycosides, terpenoids, flavonoids, alkaloids, tannins while saponins, antiquinones, } \\
\text { phlobatannins and steroids were absent. On the other hand, Synedrella nodiflora leaf } \\
\text { extract showed the presence of carbohydrates, alkaloids, steroids, tannins, phlobatannins } \\
\text { and saponins; however, flavonoids, terponoids, glycosides and antiquinones were } \\
\text { absent. The significant of this work lies in the use of both plants in the treatment of } \\
\text { important ailments, Synedrella nodiflora for measles, stimulants, relaxant, malaria, etc. } \\
\text { and Vossia cuspidata are used for skin burns, bed sore, cough, wounds and } \\
\text { inflammation. }\end{array}$} & $\begin{array}{l}\text { Accepted: } 13 \text { July } 2016 \\
\text { Available Online: } 06 \text { August } 2016\end{array}$ \\
\hline & Keywords \\
\hline & $\begin{array}{l}\text { Medicinal plants } \\
\text { Phytochemical constituents } \\
\text { Synedrella nodiflora } \\
\text { Vossia cuspidata }\end{array}$ \\
\hline
\end{tabular}

\section{Introduction}

Medicinal plants are of great importance to the health of individuals and communities. These plants are known to possess some chemical substances that have definite physiological action on the tissues of organisms. Recent scientific investigation by the World Organization shows that more than a billion people rely on herbal medicine to treat ailments and over twenty one thousand $(21,000)$ plants has been reported to have medicinal uses including Synedrella nodiflora and Vossia cuspidata (Das and Bruitin, 2000). Modern drugs are more so gotten from these medicinal plants. Components of the plants are extracted, purified and manufactured into drugs. However, the constituents of some medicinal plants have not be isolated and characterized (Odebiyi and Sofowora, 1978).

The plant Synedrella nodiflora belonging to the family of Asteraceae with the genus Synedrella, is an erect herb of about $50-90 \mathrm{~cm}$ tall, branched leaves and a major weed, in garden and immediate environment (road sides, houses) and grows best where the soil is moist and fertile (Stone, 1970; Swarbrick, 1997; Wagner et al., 1999).

The stem is soft and hence commonly been fed upon by animals (pasture). Vossia cuspidata is a perennial aquatic grass, about $7 \mathrm{~m}$ long and $1 \mathrm{~cm}$ in diameter. The stems are round and hallow at the internodes. Have sessile spikelets up to $10 \mathrm{~mm}$ long. There is roofing at 
submerged nodes, putting up an aerial stems. They are mostly found in the rainforest areas of the world (Asia, India, China and Africa). Some other similar species exist but however with each confined to a particular area e.g. Saccharum sinensis (Chinese rainforests), Saccharum barberi (Indian rainforests) and Saccharum spontaneous (Asian rainforests). Vossia cuspidata is a species of cane sugar that can tolerate abthracnose, bacteria and fungus diseases. They can resist drought, high $\mathrm{pH}$, loamy soil, virus and water log area (Duke, 1978). The aim of the present research work was to extract, identify the bioactive compounds present in Vossia cuspidata and Synedrella nodiflora and to be able to relate these bioactive compounds to their uses in the treatment of diseases.

\section{Materials and methods}

\section{Preparation of samples}

The leaves of Synedrella nodiflora were obtained from the premises of Kogi State University, Anyigba, Nigeria and were washed to remove dirts and impurities. The gel in the leaves was removed and kept in the refrigerator. Some of the leaves were sun dried for two weeks, crushed in a mortar and further reduced into a coarse powder by using an automated grinder. The powdered leaves sample we stored in polythene bag, imbedded and kept in the oven. The stem of Vossia cuspidata were obtained from Omala Local Government Area of Kogi State, washed to remove dirts and impurities. Using knife, the bark of the stem was removed. Some of the stem were crushed to remove the gel out and stored in a test tube in refrigerator. While some of the sterns were reduced to powder and kept in the oven to dry in the laboratory. They were further reduced to coarse powder by blending with a blender and kept in the oven for further analysis.

\section{Procedures used for the extraction}

Three extraction procedures were used, namely: the Soxhlet extraction method, aqueous extraction method, and wet extraction method.

(i) Soxhlet extraction: $10 \mathrm{~g}$ of the powdered sample of Vossia cuspidata was weighed and placed in the thimble of the soxhlel extractor. $250 \mathrm{ml}$ of chloroform was measured into the flask of Soxhlet extractor, 4 antibumping chips were placed on the organic solvent to prevent overheating and spill over. The Soxhlet extractor was connected and fixed tight to the round bottom flask. The extraction lasted for 6 hrs and stopped when the organic solvent condensing at the thimble apartment was seen to be colourless, indicating total and complete extraction and the result was recorded.

(ii) Aqueous extraction: $10.0 \mathrm{~g}$ of the powdered sample Synedrella nodiflora was weighed into beaker and $200 \mathrm{~m} 1$ of distilled water was added. The mixture was heated to boiling for 30 minutes, left to stand for $24 \mathrm{hrs}$ and then filtered with a clean filter paper to remove particles. The filtrate was heated in a water bath until a dry residue was obtained. The residue was weighed and the percentage yield was calculated. The same procedure was used for the powdered sample Vossia cuspidata.

(iii) Wet extraction method: $10.0 \mathrm{~g}$ of the powdered samples of Synedrella nodiflora was dissolved in $300 \mathrm{~m} 1$ of chloroform. The mixture was allowed to macerate for a day (24 hrs). It was filtered using Whatman No.1 filter paper. The filtrate was allowed to evaporate to dryness and the percentage yield of the residue was calculated and the results were recorded. The same procedure was used for the Vossia cuspidata.

\section{Phytochemical analysis of extracts}

Various phytochemical analysis for the test for alkaloids, tannins, glycosides, carbohydrates, terpenoids, anthroquinones, phlobatannins, saponins, flavonoids, and steroids were carried out for aqueous sample preparations using the methods of Odebiyi and Sofowora (1978), Harborne (1973) and Sofowora (1993).

Test for tannins: About $2 \mathrm{ml}$ of the aqueous extract was stirred with 2nd of distilled water and few drops of $\mathrm{FeCl}_{3}$ solution were added. The formation of a green precipitate was an indication for the presence of tannins.

Test of saponins: $5 \mathrm{~m} 1$ of aqueous extract was shaken vigorously with $5 \mathrm{ml}$ of distilled water in a test tube and warmed. The formation of stable foam was taken as an indication for presence of saponins.

Test for phlobatannins: About $2 \mathrm{~m} 1$ of aqueous extract was added to $2 \mathrm{ml}$ of $1 \% \mathrm{HCl}$ and the mixture was boiled. Deposition of a red precipitate was taken as an for the presence of phlobatannins.

Test for flavonoids: To I $\mathrm{ml}$ of aqueous extract was added I $\mathrm{ml}$ of $10 \%$ lead acetate solution. The formation of a yellow precipitate was taken as a positive test for flavonoids. 
Tests for anthraquinones- Borntrager's test: $3 \mathrm{ml}$ of aqueous extract was shaken with $3 \mathrm{ml}$ of benzene, filtered and $5 \mathrm{ml}$ of $10 \%$ ammonia solution was added to the filtrate. The mixture was shaken and the presence of a pink, red or violet colour in the ammonical (lower) phase indicates the presence of free anthraquinones; 3 $\mathrm{ml}$ of the aqueous extract was boiled with $3 \mathrm{~m} 1$ of aqueous sulphuric acid and filtered while hot. $3 \mathrm{ml}$ of benzene was added to the filtered shaken. The benzene layer was separated and $3 \mathrm{ml}$ of $10 \% \mathrm{HN}_{3}$ added. A pink, red or violet colouration in the ammonical (lower) phase indicates the presence of anthraquinone derivatives.

Test for terpenoids: $2 \mathrm{ml}$ of the organic extract was dissolved in $2 \mathrm{ml}$ of chloroform and evaporated to dryness. $2 \mathrm{ml}$ of concentrated sulphnric acid was then added and healed for about $2 \mathrm{~mm}$. A grayish colour indicates the presence of terpenoids.

Tests for steroids: A red colour produced in the lower chloroform layer $2 \mathrm{ml}$ of organic extract was dissolved in $2 \mathrm{ml}$ of chloroform and $2 \mathrm{ml}$ concentrate sulphuric acid added indicates the presence of steroids; The development of a greenish colour when $2 \mathrm{ml}$ of the organic extract was dissolved in $2 \mathrm{ml}$ of chloroform and treated with sulphuric and acetic acids indicates the presence of steroids.

Test for alkaloids: $3 \mathrm{ml}$ of aqueous extract was stirred with $3 \mathrm{ml}$ of $1 \% 110$ on a steam bath. Mayer's and Wagner's reagents were then added to the mixture. Turbidity of the resulting precipitate was taken as evidence for the presence of alkaloids.

Tests for carbohydrates-Molisch's test: $3 \mathrm{ml}$ of the aqueous extract was added to $2 \mathrm{ml}$ of Molisch's reagent and the resulting mixture shaken properly, $2 \mathrm{ml}$ of concentrated $\mathrm{H}_{2} \mathrm{SO}_{4}$ was then poured carefully down the side of the test tube. A violet ring at (be interphone indicates the presence of carbohydrate; To $3 \mathrm{ml}$ of the aqueous extract was added about $1 \mathrm{ml}$ of iodine solution. A purple coloration at the interphone indicates the presence of carbohydrates.

Tests for glycosides-(a) Liebermann's test: $2 \mathrm{ml}$ of the organic extract was dissolved in $2 \mathrm{ml}$ of chloroform and 2 $\mathrm{ml}$ of acetic acid was added carefully. A color change from violet to blue to green indicates the presence of a steroidal nucleus (that is, a glycone portion of glycoside).

(b) Salkowski's test: $2 \mathrm{ml}$ of each extract was dissolved in $2 \mathrm{ml}$ of chloroform. $2 \mathrm{ml}$ of sulphuric acid was added carefully and ahaken gently. A reddish brown colour indicates the presence of a steroidal ring (that is a glycone portion of glycoside).

(c) Keller-Kiliani test: $2 \mathrm{ml}$ of each extinct was dissolved in $2 \mathrm{ml}$ of glacial acetic acid containing $\mathrm{I} \mathrm{ml}$ of concentrated $\mathrm{H}_{2} \mathrm{SO}_{4}$ characteristic of cardenolides.

\section{Results and discussion}

The yield for the Soxhlet extraction was relatively higher for both Vossia cuspidata and Synedrella nodiflora, as compared with the aqueous and wet extraction method used. The organic solvent, chloroform should extract more of the natural products in the plant materials than water, since most of its components are organic compounds, while in addition the temperature and the time used were other factors that affect the yield. A yield of $11.85 \%$ was obtained for Synedrella nodiflora in Soxhlet extraction as compared to 9.05 and $5.30 \%$ obtained from aqueous extraction and wet extraction respectively. While the yield for the Vossia cuspidata was $14.0 \%$ for Soxhlet extraction method as compared with $7.85 \%$ and $12.6 \%$ for aqueous extraction and wet extraction respectively (Table 1 ).

Table 1. Extract yield obtained in Soxhlet extraction, aqueous extraction and wet extraction of Vossia cuspidata stem and Synedrella nodiflora leaves in percentage.

\begin{tabular}{lll}
\hline Extraction method & Vossia cuspidata & Synedrella nodiflora \\
\hline Soxhlet extraction & $14.0 \%$ & $11.85 \%$ \\
Aqueous extraction & $7.85 \%$ & $9.05 \%$ \\
Wet extraction & $12.6 \%$ & $5.3 \%$ \\
\hline
\end{tabular}

Phytochemical screening of the Synedrella nodiflora leaves indicated the presence of alkaloids, tannins, saponins, carbohydrates and steroids while flavonoids, glycosides, terpenoids, phlobatannins, anthroquinones were found to be absent (Table 2). This justified the use of
Synedrella nodiflora as medicinal plant (anti-malaria agent, stimulants relaxant) while phytochemical analysis of the Vossia cuspidata stem extract indicated the presence of glycosides, terpenoids, carbohydrates, alkaloids, flavonoids and tannins with steroids, 
phlobatannins, anthroquinones saponins giving a negative result (Table 2). The presence of these bioactive agents made the plant useful in anti-inflammation, anti-ulcer, skin protection and relaxative (Begum et al., 2002).

The percentage yield of extracts for both plants Synedrella nodiflora and Vossia cuspidata were relatively small, although appreciable with the extraction by the Soxhlet method being higher with a value of $11.85 \%$ and $14.0 \%$ respectively. The phytochemical screening shows both plants contain some bioactive compounds (Synedrella nodiflora and Vossia cuspidata). This had made them to show medicinal activities as well as exhibiting some physiologic effects (Sofowora, 1993).

Table 2. Phytochemical constituents in aqueous extracts of Vossia cuspidata stem and Synedrella nodiflora leaves.

\begin{tabular}{lll}
\hline Phytochemical constituents & Vossia cuspidata (stem) & Synedrella nodiflora (leaves) \\
\hline Alkaloids & + & + \\
Tannins & + & - \\
Saponins & - & + \\
Flavonoids & + & + \\
Steroids & - & - \\
Glycosides & + & + \\
Carbohydrates & + & - \\
Anthroquinones & - & - \\
Phlobatannins & - & - \\
Terpenoids & + &
\end{tabular}

+ present; - absent;

Alkaloids that were found to be present in both plants have physiological effects on patient such as loss of consciousness during operation, use for treatment of cough, asthma and hay-fever. Saponins present in Synedrella nodiflora are a class of glycosides that causes foaming and its effect include hemolysis of red blood cell, use as expectorants for shampoo, tooth paste, and cosmetic preparation. Tanning had been used to control ulcer, diarrhea, hemorrhage, dysentery and deep burns (Hayashi et al., 1993). However the absence of flavonoids in Synedrella nodiflora is in contrast with the opinion of Gill (1992), who noted that flavonoid is one of its bioactive constituents. The vague variation could he clue to experimental error. Both plants had been in immense value to man right from time immemorial while at present, much importance is attached to the native use of these plants as herbal medicine in remote areas of the world where the modem science is lacking. The plant studied here (Synedrella nodiflora and Vossia cuspidata) can be seen as potential source for useful drugs.

\section{Recommendations}

(1) Researchers should go for their isolation, identification, characterization and elucidation of the structure of the actual bioactive compounds present in both plants.

(2) Finding out an acceptable dosage level of consumption for the plant extracts, as excessive consumption would be dangerous.

(3) Drug manufacturers should explore good use of
Synedrella nodifiora and Vossia cuspidata extracts as a cheap precursor for the manufacturing of drugs.

(4) Further steps need to be taken to actually purity the local extract before being consumed locally to avoid health hazards.

\section{Conclusion}

The usefulness of Synedrella nodiflora and Vossia cuspidata cannot be overemphasized in the local treatment of diseases such as measles, malaria, skin treatment etc with bioactive agents been identified with the plants that are responsible for their medicinal roles. Further studies are going on these plants in order to isolate, identify, characterize and elucidate the structure of the bioactive compounds while anti microbial activities of the plants for the treatment of diseases as claimed by traditional healers are also being investigated.

\section{Conflict of interest statement}

Authors declare that they have no conflict of interest.

\section{References}

Begum, S. N., 2002. Triterpenoids from the stem of Saccharum barberi Jewsiet. Phylochemistry. 61(4), 399403.

Das, S.F., Brutin, J.G., 2000. Screening of Plant for Biologically Active Substances in Africa Medicinal Plant (Ed.: Sofowora, A.). Obafemi Awolowo University Press, Nigeria. 
Duke, J.A., 1978. The quest for tolerant germplasm. In: ASA Special Symposium 32, Crop Tolerance to Suboptimal Land Conditions. Am. Soc. Agron. Madison, WI. pp.1-61.

Gill, L.S., 1992. Ethnomedical Uses of Plants in Nigeria. University of Benin Nigeria. 276p.

Harborne, J.B., 1973. Phytochemical Methods. Chapman and Hall Ltd., London. pp.49-188.

Hayashi, T., Okamuka, K., Kawasaki, M., Monta, N., 1993. Production diterpenoids by cultured cells from two chemotypes Scoparia dulcis. Photochem. 15(2), 353-355.

Odebiyi, O.O., Sofowora, A., 1978. Phytochemical Screening of Nigeria Plants. 1-2 OAU/STRC Inter African Symposium on Traditional Pharmacopoeia and Africa
Medicinal Plants OAU/STRC Publish No.115, Lagos. $296 \mathrm{p}$.

Sofowora, A., 1993. Medicinal Plants and Traditional Medicine in Africa. Spectrum Book Ltd., University of Ife Press, Nigeria. 119p.

Stone, I. C., 1970. The Flora of Guam. Micronesica. 6, 585586.

Swarbrick, J.T., 1997. Weeds of Pacific Islands, Technical Paper No. 299 South Pacific Commission. New Caledonia. 197p.

Wagner, W.L., 1999. Manual of the Flowering Plants of Hawai. Revised Edition. University of Hawai Press, Honolulu. 360p.

\section{How to cite this article:}

Raphael, E., Momoh, S., Kayode, D., Gideon, A., Friday, E. T., 2016. The phytochemical constituents of Vossia cuspidata and Synedrella nodiflora. Int. J. Curr. Res. Biosci. Plant Biol. 3(8), 53-57.

doi: http://dx.doi.org/10.20546/ijcrbp.2016.308.008 